\title{
A COMPANHIA SIDERÚRGICA NACIONAL (CSN) E AS POLÍTICAS SOCIAIS DE LAZER PARA OS TRABALHADORES: OS CLUBES SOCIORRECREATIVOS
}

Recebido em: 18/02/2015

Aceito em: 15/09/2015

Fábio Salgado Araújo

Universidade do Estado do Rio de Janeiro - UERJ ${ }^{1}$

RESUMO: O presente artigo busca compreender as políticas sociais de lazer instituídas pela Companhia Siderúrgica Nacional (CSN) discutindo a influência da empresa sobre o tempo livre de seus trabalhadores. A CSN representava na década de 1940 a construção de um projeto de caráter nacional-desenvolvimentista que procurava criar uma nova concepção de relação entre o Estado e a classe trabalhadora, inclusive no tempo do não trabalho, com a promoção de atividades de lazer. O lazer oferecido e fomentado pela CSN tinha como característica atender, preservar, recuperar e aumentar a capacidade de produzir do trabalhador apresentando características do momento industrial-fordista no Brasil com destaque para as atividades sócio-culturais e esportivos que acontecia principalmente nos clubes sociorrecreativos vinculados a empresa.

PALAVRAS CHAVE: Atividades de Lazer. Trabalhadores. Política Social.

\section{THE COMPANY NATIONAL STEEL (CSN) AND THE LEISURE SOCIAL POLICIES FOR WORKERS: CLUB SOCIAL AND RECREATIONAL}

ABSTRACT: This article seeks to understand the social policies of leisure imposed by the National Steel Company (CSN) discussing the influence of the company on the free time of its workers. CSN represented in the 1940s to build a national-developmentalist character design that sought to create a new conception of relationship between the state and the working class, including the non-work time with the promotion of leisure activities. The leisure offered and promoted by CSN had characterized meet, preserve, restore and enhance the ability to produce worker presenting characteristics of industrial-Fordist time in Brazil with emphasis on socio-cultural and sports activities that occurred mainly in sociorrecreativos clubs linked to company.

KEYWORDS: Leisure Activities. Workers. Public Policy.

\footnotetext{
${ }^{1}$ Doutorando em Geografia pelo programa de Pós-Graduação em Geografia (PPGEO/UERJ). Este artigo faz parte da dissertação intitulada $O$ Lazer em Volta Redonda-RJ: dos clubes sociorrecreativos vinculados a Companhia Siderúrgica Nacional (CSN) aos novos investimentos esportivos da prefeitura sob orientação do professor Miguel Ângelo Campos Ribeiro.
} 


\section{Introdução}

O processo de industrialização a partir dos investimentos estatais nas décadas de 1930 e 1940 representava a construção de um projeto de caráter nacionaldesenvolvimentista ligado à ideologia de Getúlio Vargas. Este projeto procurava criar uma nova concepção de relação entre o Estado e a classe trabalhadora, ideais esses que foram incorporados no processo de criação e implantação da CSN. Por isso, o projeto tinha um determinado padrão de planejamento, uma espécie de modelo de gestão urbano-industrial. Assim, a empresa estava presente em todas as esferas da vida de seus operários, inclusive no tempo do não trabalho, com a promoção de atividades de lazer (MOREL, 1989).

O lazer oferecido e fomentado pela empresa tinha como característica atender, preservar, recuperar e aumentar a capacidade de produzir do trabalhador apresentando características do momento industrial-fordista no Brasil. Assim, no processo de consolidação da empresa e da cidade, as atividades sócio-culturais e esportivas foram difundidas através de diversas instalações nas décadas de 1940, 1950 e 1960. Essas atividades aconteciam principalmente nos clubes sociorrecreativos vinculados a empresa.

A partir do final da década de 1970, a empresa começa a reduzir seus investimentos desfazendo do seu patrimônio e dos encargos decorrentes de sua manutenção e consequentemente diminuindo os investimentos sociais incluindo aqueles relacionados ao lazer. Com isso, não há mais atividades sócio-culturais e esportivas fomentadas pelas empresas tendo os clubes sociorrecreativos buscar outras formas de manterem seu funcionamento e a promoção de atividades. 


\section{A Companhia Siderúrgica Nacional e a Criação da Cidade Empresa}

A história do município começou no século XVIII com a colonização do médio Vale do Paraíba Fluminense estando ligado ao ciclo do café. Entretanto, com a escolha do local para a instalação da Companhia Siderúrgica Nacional (CSN) na década de 1940, grandes mudanças estavam por vir. A cidade juntamente com a siderúrgica foi planejada a partir do modelo de cidade industrial do arquiteto francês Tony Garnier, adaptado pelo também arquiteto Attílio Corrêa Lima ao autoritarismo populista de Getúlio Vargas. O objetivo era transformar Volta Redonda numa cidade modelo, uma experiência exemplar com um planejamento residencial que evidenciasse a hegemonia dos mais graduados na empresa.

De acordo com Lopes (1993), o plano de Volta Redonda deveria contribuir para exaltar o industrialismo, sublinhar a política social do governo e espacializar, através do desenho e do equipamento da cidade, o homem novo que estava sendo construído. A elaboração do plano urbanístico da cidade foi influenciada pelo modelo urbanístico norte-americano com o zoneamento indicando especialização por área e ordenação dos fluxos, inclusive as áreas e equipamentos destinados ao lazer. Previa uma cidade linear, com desenho simples e equilibrado com as funções principais bem articuladas. A área central seria ocupada pelo centro comercial, desenvolvendo-se paralelamente à usina e concentrando a infraestrutura. A CSN seria um modelo autárquico onde a empresa utilizava diversas estratégias para educar, vigiar e controlar o trabalhador dentro e fora da fábrica. A estrutura da vila operária reproduzia a estrutura disciplinar da usina, com arranjo espacial que representava essa ordem, havendo com isto, um duplo controle dos

trabalhadores configurando uma verdadeira company-town. (CALIFE, 2000; MOREIRA, 2000; FONTES e LAMARÃO, 2006; PIQUET, 1998). 
O não aproveitamento de todos os trabalhadores da construção da Usina gerou uma desmobilização da mão-de-obra empregada na construção acarretando um crescimento desordenado e desvinculado dos interesses imediatos da empresa. Com isso, na margem esquerda do Rio Paraíba do Sul surgia outra Volta Redonda, ocupada de forma não planejada por pequenos comerciantes e por aquela massa de trabalhadores dispensados pela empresa. Os dois núcleos originais do então povoado tornaram-se eixo de ligação entre os bairros planejados e os novos bairros surgidos nesse processo de crescimento.

Assim, Volta Redonda ficaria dividida em duas: à margem direita do rio desenvolvia-se o núcleo urbano a partir do projeto dos bairros operários - a chamada de Cidade Nova - e à margem esquerda a Cidade Velha, separada da CSN e que não dispunha dos serviços da parte planejada. Os trabalhadores não aproveitados pela CSN foram deslocados para a parte Velha ou para a periferia da cidade, e os proprietários de fazendas da região se converteram em loteadores e especuladores. Com isso, a cidade conheceu uma considerável expansão da malha urbana com a implantação de numerosos loteamentos dando origem a novos bairros, principalmente na margem esquerda do Rio Paraíba do Sul (FIGURA 1). O processo de ocupação de Volta Redonda gerou uma malha urbana descontínua e rarefeita, com grandes vazios e áreas urbanas enquistadas, subindo os morros e instalando-se em pequenas áreas de baixada. Não apenas as características físicas definiram tal ocupação, mas, principalmente, o fato de as melhores terras estarem nas mãos da CSN e de alguns fazendeiros (CALIFE, 2000; MOREIRA 2000; FONTES e LAMARÃO, 2006). 
Figura 01 - Mapa com a expansão dos bairros de Volta Redonda entre 1940 e 1970.

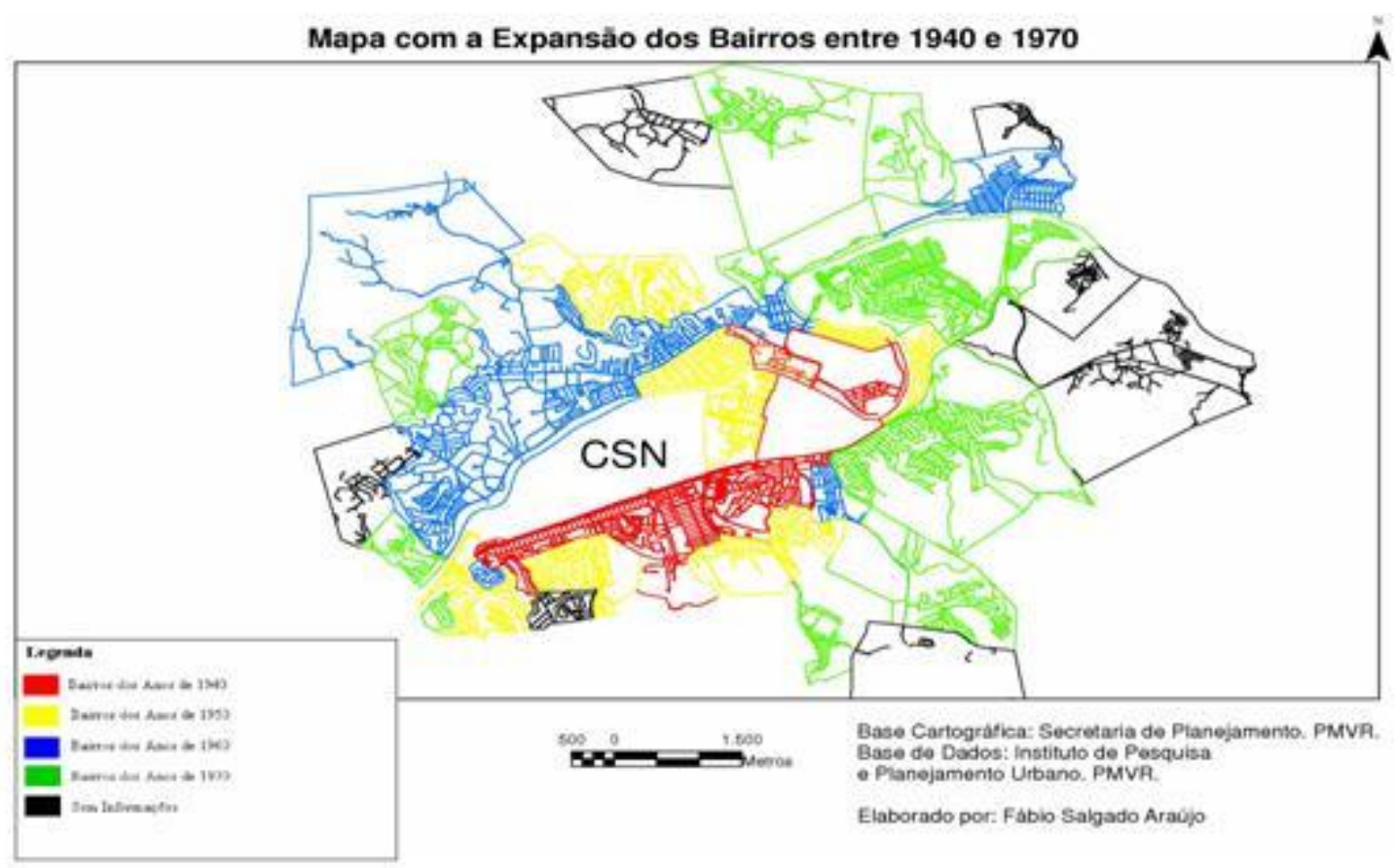

Elaborado por: Araújo, 2013.

Nas décadas de 1960 e 1970, a CSN começou a reduzir seus encargos com moradias para funcionários vendendo as casas através da criação de uma imobiliária e também desfez de seu patrimônio público - ruas, praças, serviços urbanos etc. - e dos encargos decorrentes de sua manutenção passando para a Prefeitura Municipal. Assim, em 1968, a prefeitura e a CSN assinaram um termo de entrega e recebimento dos serviços urbanos, dando início ao processo de unificação do espaço urbano ao reunir, sob a mesma administração, a cidade operária e a cidade velha. Essa medida foi responsável pela multiplicação dos encargos da administração municipal sem que esta se encontrasse preparada para tanto, para o fornecimento desses serviços. O impacto foi significativo, pois até mesmo a água que abastecia os bairros da cidade planejada era fornecida pela CSN (COSTA, 1992).

A crise na década de 1980 e acúmulo de dívidas da CSN foram fatores que contribuíram para a estagnação econômica do município. As políticas governamentais 
em nível nacional, empreendidas a partir do fim da década de 1980, levaram ao processo de privatização da usina em 1993, dando origem a maior crise vivida pelo município ao longo de sua história. Com a privatização houve uma diminuição da intervenção da siderúrgica diretamente sobre a cidade, com a sua retirada na dotação de infraestrutura urbana e o término das políticas sociais empreendidas pela empresa, incluídas aquelas relacionadas ao lazer. Assim, poder público municipal tem aumentado sua presença e poder no fomento de políticas públicas e sociais.

\section{Os Clubes Sociorrecreativos Enquanto Instrumento de Políticas de Lazer}

De acordo com Lopes (1993), no plano original de Volta Redonda quase não havia menção a equipamentos de lazer. ${ }^{2}$. Todavia, no processo de consolidação da empresa e da cidade, os esportes e as atividades culturais/artísticas foram amplamente difundidos através de diversas instalações construídas ao longo das décadas de 1940 e 1950, como clubes sociorrecreativos, cinemas, rádio e entidades artísticas e culturais. Com isso, a difusão das atividades físicas e culturais promovidas pela empresa contribuiu para forjar uma identidade coletiva e subjetiva através do entretenimento de massa e da propaganda do governo, promovendo a família siderúrgica ${ }^{3}$.

Para esse modelo de sociedade industrial-fordista, era necessário forjar o trabalhador adequado, e para tal era preciso pôr em ação elementos que permitissem uma conotação mais positiva do trabalho industrial. Este passava então a possuir

\footnotetext{
${ }^{2}$ Era previsto apenas um local de recreação (Parque Ribeirão da Cachoeira), um cineteatro, um playground junto à escola e somente um conjunto esportivo. $\mathrm{O}$ cineteatro foi concretizado alguns anos depois. No local do playground foi construído um clube sociorrecreativo. O local original para a construção do Parque foi transformado em praça. O conjunto esportivo foi concluído alguns anos depois.

3 Termo cunhado pela autora Regina Morel (1989) ao modelo de gestão aplicado no início de funcionamento da empresa que diz respeito às várias esferas de atuação da companhia para além do trabalho (habitação, saúde, educação, lazer, etc.), com o intuito de construir adesão e consenso dos trabalhadores em torno do projeto.
} 
atributos morais como honestidade, respeitabilidade e honradez. Algumas práticas do tempo do não trabalho existentes eram desqualificadas, como os jogos de azar, as apostas, rinhas de animais, o consumo de bebidas alcoólicas e tudo que era considerado excesso. Para aqueles que cometiam excessos e se desviavam das normas, havia todo um aparato repressor pronto para entrar em ação. Destaque-se aí a atuação da Polícia Política, que tinha o objetivo de entrever e coibir comportamentos políticos divergentes, considerados capazes de comprometer a ordem e a segurança pública.

No caso da CSN, o interesse da empresa era instituir uma ordem social no espaço urbano criado por ela, utilizando-se para isso de inúmeros dispositivos que pudessem auxiliar na contenção dos excessos e desvios de normas no tempo do não trabalho de seus empregados. Neste contexto, podem-se citar a função que desempenharam os meios de comunicação estabelecidos pela siderúrgica, como o jornal O Lingote, que começou a circular em 1953 e a criação da Rádio Siderúrgica Nacional em 1955. Estes tinham a finalidade de transmitir os valores da empresa para os funcionários e seus familiares. Assim, de acordo com Moreira (2000, p. 55), a política social incluía:

[...] medidas de proteção à saúde física e mental do homem brasileiro, mas também de incentivo à sua capacidade produtiva. Nesse sentido, a satisfação de necessidades básicas como habitação, alimentação, saúde e educação, assim como o amparo à família, acabariam por tornar-se pontos primordiais da política estadonovista de proteção ao trabalhador e ao próprio progresso material do país.

Portanto, entre os elementos importantes estaria o desenvolvimento de atividades de lazer. Nessa leitura/concepção, o lazer é visto como um recurso para condicionar corpos, mentes e espíritos às exigências da nova civilização mecânica e colocá-los em sintonia com os princípios e valores morais que regem a sociedade 
moderno-industrial de caráter fordista em formação no país. (DUMAZEDIER, 1979; PARKER, 1976)

O lazer oferecido pela empresa tinha como objetivo recuperar os trabalhadores para o trabalho vindouro e, além disso, compensar os desgastes originados nas atividades obrigatórias. Pois de acordo com Dumazedier $(1973,1979)$ dessa forma, se por um lado o ritmo de trabalho pesado na gerava o cansaço, a fadiga, a alienação, por outro o lazer deveria proporcionar a recuperação, o descanso e a compensação, sendo este visto pela empresa no seu aspecto compensatório e utilitarista. Assim, a empresa usava o tempo do não trabalho de seus funcionários com o objetivo de promover a manutenção da força de trabalho.

Tendo em vista tais interesses, a empresa promovia uma série de atividades no tempo do não trabalho, procurando imprimir seus valores e ideais também no tempo do lazer, quando as influências coletivas e sociais tendem a ser mais fortes do que as individuais. O incentivo aos esportes, principalmente os coletivos, e a promoção de atividades de socialização, como bailes e shows musicais com a participação dos trabalhadores e seus familiares, eram momentos em que a empresa fazia valer seus princípios e ideologia de modo implícito. Em contrapartida, possibilitava a seus trabalhadores acesso a bens inatingíveis a grande parte da sociedade brasileira no período.

Assim, a empresa procurava criar e fomentar uma variedade de atividades de lazer para os funcionários e seus familiares. Destaca-se, principalmente entre as décadas de 1950, 1960 e 1970, os espetáculos teatrais e musicais, realização de festas com apresentação de artistas conhecidos nacionalmente, além exibição de filmes nos cinemas, torneios esportivos, maratonas estudantis, entre outras comemorações 
diversas. Essas atividades contavam com a participação da população siderúrgica, e na maioria das vezes os eventos realizados procuravam atender a preferência popular dos trabalhadores, certamente influenciada pelos meios de comunicação.

Entretanto, existia uma diferença no lazer praticado entre os trabalhadores mais qualificados e aqueles com menor qualificação. As atividades destinadas aos trabalhadores menos qualificados consistiam em peças de teatro amador, domingueiras dançantes, bailes de cunho popular organizados pelos próprios trabalhadores ou pela Superintendência de Serviços Sociais da CSN. Essas festas eram realizados no Círculo Operário de Volta Redonda, no Cinema Santa Cecília, no Clube Náutico e Recreativo Santa Cecília e no Clube Recreio do Trabalhador, além de utilizarem o refeitório dos engenheiros e o refeitório do acampamento central. Já para a elite dos empregados da empresa e suas famílias, o Hotel Bela Vista cedia os seus salões para os bailes e festas do Clube Funcionários da CSN e do Clube Umuarama - que mais tarde passaram a organizar os bailes em suas próprias sedes.

Destacavam-se os bailes de carnaval, réveillon, festa junina e páscoa, além das festas em feriados e datas cívicas, como dia do trabalhador, independência do Brasil e proclamação da República. Entretanto, a data em que se organizavam as maiores festividades era o dia 9 de abril, aniversário da $\mathrm{CSN}$, quando eram realizadas competições, shows, bailes etc., além de ser também um momento de promoção do discurso da empresa que se comprometia socialmente com seus funcionários (FIGURA 02). Todo o conjunto das atividades de entretenimento realizadas objetivava preencher o tempo disponível do trabalhador, em detrimento da liberdade que ele teria para realizar as atividades de lazer que gostaria. Influenciados pela propaganda da empresa, eles participavam ativamente das atividades de lazer oferecidas pela empresa. 
Figura 02 - Entrega de distintivos, diplomas de 10 anos e chaves de novas residências no Ginásio do Recreio do Trabalhador, durante as festividades em comemoração ao $15^{\circ}$ aniversário da CSN, em 1956.

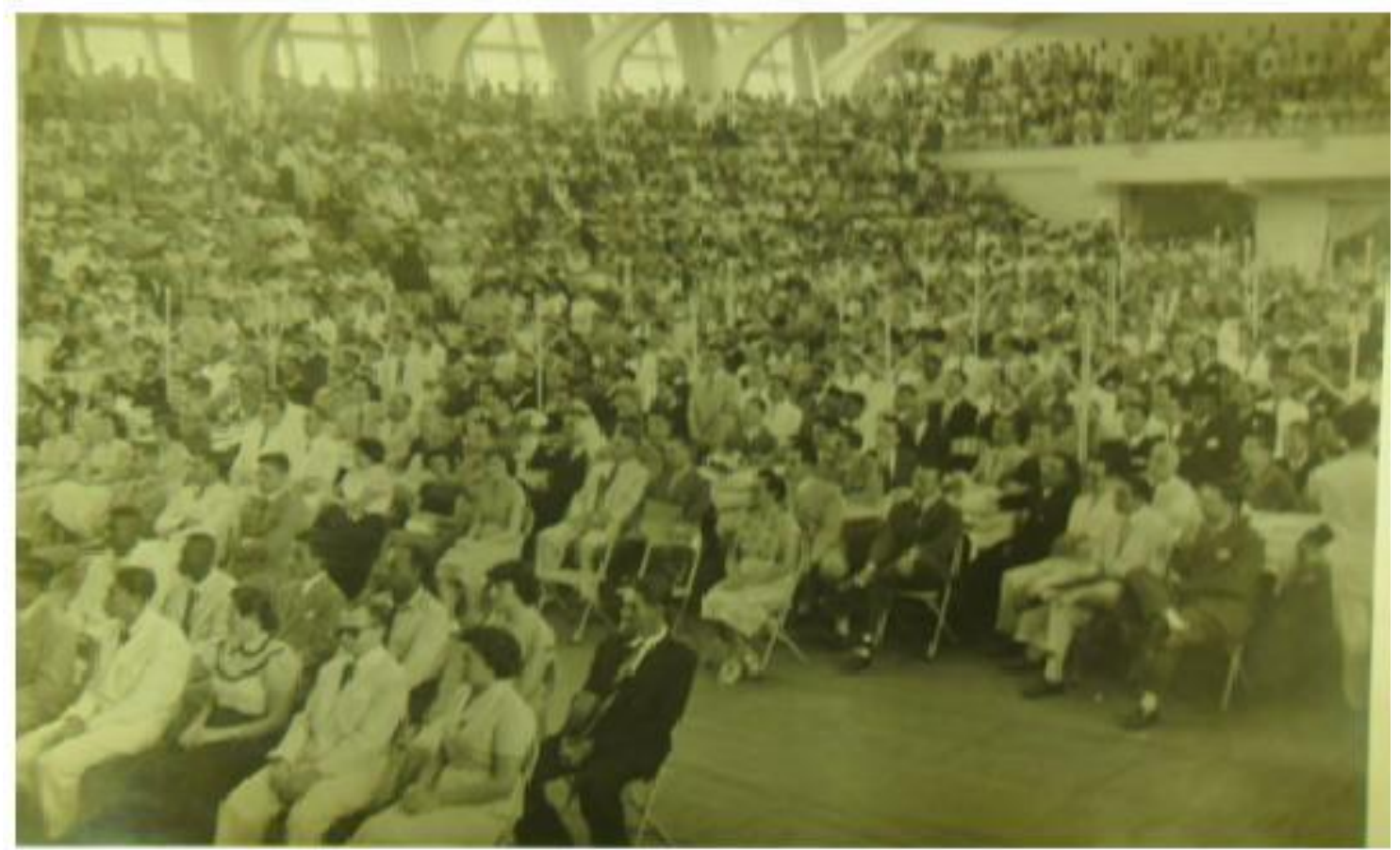

Fonte: ARQUIVO CENTRAL DA CSN, 2013.

Em relação aos esportes, a principal associação que realizava competições atléticas era a Liga de Desportos de Volta Redonda (LDVR), um órgão normativo criado em 1945 e que tinha considerável apoio da CSN. O objetivo da Liga era, conforme seu estatuto,

[...] dirigir, difundir e incrementar, por intermédio das associações e agremiações que lhe estão filiadas, os desportos de sua competência, com caráter amadorista ou profissional adiante especificados [...] e os que venham a reger no território do município de sua jurisdição ${ }^{4}$.

De acordo com Bêde (2004), muitas competições atléticas foram promovidas pela LDVR de forma altamente produtiva, em consonância com os objetivos da empresa, dando ênfase aos esportes coletivos como o futebol, o vôlei e o basquete, tendo os clubes sociorrecreativos como locais para a realização desses eventos esportivos. Essa importância dada pela empresa aos esportes tinha como propósito

\footnotetext{
${ }^{4}$ LIGA DE DESPORTOS DE VOLTA REDONDA, 2012. Informações retiradas no site da entidade: http://www.ldvr.com.br/institucional.php
} 
“estimular um espírito associativo entre os empregados da CSN e proporcionar-lhes um entretenimento sadio $5 "$ ". Eventos ilustrativos dessa ideologia são as "Olimpíadas Siderúrgicas” e os “Jogos Siderúrgicos” criados na década de 1950.

No que tange às atividades socioculturais, era o Grêmio Artístico e Cultural Edmundo de Macedo Soares e Silva (GACEMSS) a principal associação a realizar eventos, que eram destinados principalmente aos funcionários mais graduados da CSN. O GACEMSS foi fundado em 1945 a partir de um grupo de trabalhadores da empresa que desejavam construir em Volta Redonda um teatro para realização de peças, recitais e concertos de música erudita. O apoio da CSN foi concretizado com a venda, a preço simbólico, de um terreno para que o Grêmio pudesse construir a sua sede e o teatro. A construção foi iniciada em 1961, e sua conclusão deu-se somente em 1987. O edifício possui, ainda hoje, um teatro de 150 lugares e outro com 450, além de espaços para exposições de $\operatorname{artes}^{6}$. Antes de sua sede ficar pronta, o GACEMSS realizava suas atividades no auditório do Grupo Escolar Trajano de Medeiros ${ }^{7}$, no Cinema 9 de abril e nos clubes Umuarama e Funcionários da CSN. Na época houve apresentação de peças teatrais vindas do Rio de Janeiro, como "Natal na Praça", que contava com a atuação de Tônia Carrero, Adolfo Celli e Paulo Autran; além de teatro amador produzido pelo próprio Grêmio, como a peça "O Tempo e os Conways", com artistas como Maria Thereza Dutra Ponchio e Roberto Sanchez.

Entretanto, de acordo com Bêde (2004), os operários também procuravam aproveitar suas horas de lazer em animados "bate-papos", jogos de damas e baralhos ou simplesmente passeando com as famílias entre as áreas abertas e praças, onde

\footnotetext{
5 “Já Começou a Olimpíada Siderúrgica” Jornal O Lingote, ano II, Rio de Janeiro, 1954, no 40, p. 11.

${ }^{6}$ GRÊMIO ARTÍSTICO E CULTURAL EDMUNDO DE MACEDO SOARES E SILVA - GACEMSS, 2013. Para mais informações, acessar: http://www.gacemss.com.br/v1/page/quemsomos.asp

${ }^{7}$ O Grupo Escolar Trajano de Morais atualmente é o Instituto Estadual Manuel Marinho.
} 
vendedores de doces, salgados e cachorro-quente circulavam. Com isso, os trabalhadores ocupavam o tempo do não trabalho não somente nas atividades de lazer que eram oferecidas e estimuladas pela CSN, mas também estabeleciam no seu cotidiano outros modos de diversão. Mas talvez isso esteja relacionado com o fato de que, conforme apontamento feito pelo autor, as atividades promovidas ou fomentadas pela CSN não contemplassem toda a população.

Sobre o oferecimento de atividades socioculturais e esportivas, o levantamento feito no jornal $O$ Lingote apontou uma grande quantidade delas na década de 1950. Mas se tratava de atividades organizadas pela siderúrgica ou por entidades ligadas a ela, o que implicava que não contemplavam a população total da cidade. Essa concentração de atividades restritas fez com que muitos moradores de Volta Redonda se queixavam da falta de opções de lazer e entretenimento na cidade durante as décadas de 1950 e 1960 , pois, fora os cinemas e as eventuais competições amadoras, não havia outras. (BÊDE, 2004)

Assim, de acordo com Bêde (2004), o carnaval, o futebol e alguns bares, além das já citadas competições esportivas e o cinema, foram as principais formas de diversão e entretenimento encontrados pelos moradores, sendo aspectos culturais e sociais que permitiram construir uma identidade comunitária para essas pessoas, muitas delas sem ligação com a empresa. As escolas de samba e os times de futebol constituíram-se como as principais atividades de lazer dos moradores dos bairros da Cidade Velha além dos jogos de malha, dominó, damas e cartas. (BEDÊ, 2004; COSTA, 1992).

Enquanto prática social, parte do lazer do operário estava vinculado à companhia, contribuindo assim para a sua alienação. Este era estimulado a consumir 
mercadorias e serviços através da participação em atividades nos clubes sociorrecreativos e nas entidades socioculturais. Assim, desenvolvia-se, por exemplo, um comércio de artigos e equipamentos esportivos fomentado pela empresa e ao mesmo tempo produzia novas energias e necessidades. Dessa forma, o lazer acabava se firmando enquanto valor utilizado pela empresa e que foi incorporado pelos trabalhadores. A CSN percebeu que, aliado ao trabalho, o lazer poderia ser utilizado no sentido de formar uma unidade, de modo que todos estivessem em prol de "um bem maior", ou seja, da construção de um projeto de Brasil moderno através do exemplo da empresa.

Contudo, as atividades oferecidas e desenvolvidas pela empresa apresentavam possibilidades de ampliação do universo cultural dos trabalhadores, pois permitiam o acesso a um conjunto de experiências e de linguagens culturais socialmente valorizadas e que em geral não faziam parte do cotidiano nesse período. O acesso a esse universo de outros conhecimentos e linguagens representava também a oportunidade de ampliar a compreensão sobre o mundo, fornecendo um conjunto de instrumentos para a reflexão da sua condição de classe trabalhadora. Assim, entre o lazer oferecido pela empresa para a classe trabalhadora e a forma como esta o utilizava existe uma distância que é permeada pela prática cotidiana dos trabalhadores, que se reapropriam daquilo que lhes é oferecido/imposto de acordo com suas vivências.

Conforme dissemos, a empresa procurava influenciar as horas de lazer do trabalhador moldando seus gostos e atividades a partir da publicidade organizada por ela. Entretanto, não podemos considerar que o tempo do não trabalho possua a mesma lógica que rege o tempo do trabalho, pois não permite capturar a complexidade do lazer praticado pelo trabalhador da empresa na Cidade Operária. O lazer pode ser um 
instrumento de dominação minimizando ou anulando o conflito social como também, a partir de interesses contraditórios e conflitantes, podem surgir elementos para a construção de uma proposta de lazer a serviço dos interesses das classes trabalhadoras. As relações existentes entre os trabalhadores e a empresa no oferecimento do lazer foram simultaneamente uma conquista da classe trabalhadora e também instrumento de dominação e hegemonia por parte da siderúrgica

Estudos como o realizado por Bêde (2004) mostra como a empresa conseguia imprimir uma dominação e hegemonia sobre os espaços tanto do trabalho como do não trabalho de seus funcionários. $\mathrm{O}$ autor afirma que, por exemplo, uma briga dentro de um dos clubes sociorrecreativos poderia refletir-se negativamente sobre $\mathrm{o}$ futuro profissional dos envolvidos. Outro exemplo é que as atividades esportivas desenvolvidas nos clubes sociorrecreativos estavam em consonância com os valores da empresa não havendo esportes que poderiam incitar a violência, como o boxe e as artes marciais. Isso nos permite afirmar que a empresa buscava controlar as diversas atividades e abre brechas para pensarmos que punições nos espaço do trabalho implicaria também em punições no espaço do não trabalho e vice-versa. Entretanto, a partir do final da década de 1960 começaram mudanças que afetaram a realização das atividades de lazer.

Conforme dissemos anteriormente, a CSN transferiu seu patrimônio para a prefeitura a partir de 1967, e a diminuição dos investimentos em infraestrutura urbana se refletiu também nos investimentos em lazer. Não há registro a partir dessa data de construções ou fomento de equipamentos de lazer pela CSN. A Companhia passou a 
atribuir maiores funções à Fundação General Edmundo Macedo Soares e Silva ${ }^{8}$ (FUGEMSS), que passou a prestar atendimento nas áreas de saúde, assistência social, cultura, educação, treinamento profissional, centralizando também o desenvolvimento de atividades de lazer da empresa. Sem contar com apoio direto da empresa, as entidades socioculturais e os clubes sociorrecreativos procuraram estabelecer-se a partir de suas próprias estruturas para o desenvolvimento de suas atividades.

Por isso, os principais equipamentos de lazer construídos pela CSN foram nas décadas de 1940, 1950 e 1960 principalmente as entidades socioculturais e os clubes sociorrecreativos. A tabela 1.0 permite a análise dos principais equipamentos de lazer, a finalidade e as principais atividades realizadas em cada um. A figura 03 mostra a distribuição dos equipamentos de lazer no espaço urbano. Assim, nota-se que os principais espaços estavam localizados no bairro Vila Santa Cecília, na parte que, de acordo com a planta geral da cidade operária, foi planejada para ser o centro comercial. Outros equipamentos de lazer estão localizados nos bairros planejados pela CSN.

Verifica-se na Tabela 1.0 e na Figura 03 que, no que se refere às políticas empreendidas pela empresa, os equipamentos de lazer de maior destaque são os clubes sociorrecreativos. Para a construção de suas sedes sociais e demais infraestruturas, eles contavam com o apoio da CSN, que geralmente cedia o uso de terrenos mediante contrato de comodato com as entidades ${ }^{9}$. Segundo informações de Silva (2008), a principal característica dos clubes sociorrecreativos é possuir uma estrutura privada constituída especificamente para oportunizar a um público restrito a prática ou fruição

\footnotetext{
8 A Fundação General Edmundo Macedo Soares e Silva (FUGEMSS) foi implantada em Congonhas (MG), em 1961, como Escola Industrial General Edmundo Macedo Soares (EIGEMSS), destinada a formar profissionais para atuarem na mineração. Convertida em FUGEMSS, passou a prestar atendimento nas áreas de saúde, assistência social, cultura, educação, treinamento e recreação, e teve a sede transferida para Volta Redonda em 1990. Em 1998, a entidade passou a se chamar "Fundação CSN". (FUNDAÇÃO CSN, 2013).

${ }^{9}$ Existiram e ainda existem outros clubes sociorrecreativos no município de Volta Redonda, entretanto, neste artigo mostramos somente aqueles ligados à CSN e seus trabalhadores.
} 
do lazer. As programações desses espaços, bem como sua estrutura física, são organizadas para contemplar um conjunto diversificado de atividades artísticas, sociais, esportivas etc.

Por possuírem vinculação com a CSN, os clubes sociorrecreativos em Volta Redonda se constituíram como clubes-empresas. Entre suas principais características estão: 1) disponibilizar sede própria para a realização de programas de lazer; 2) ser administrado por um grupo de profissionais eleito pelos votos dos associados, que despendem seu tempo livre para dirigi-lo e ainda são responsáveis pelos aspectos estratégicos e pela filosofia da instituição ${ }^{10}$; 3 ) ser associação jurídica privada sem fins lucrativos; 4) ofertar atividades diversificadas de lazer (entretanto, há predominância significativa das atividades esportivas). Os clubes sociorrecreativos eram assim considerados como instituições, espaços privados, formalmente constituídos, planejados, construídos e destinados especificamente para a prática do lazer, seja por meio de atividades esportivas, sociais ou artísticas.

Assim, nota-se uma variedade de clubes sociorrecreativos ligados aos trabalhadores da CSN. Havia os específicos para supervisores, diretores e gerentes; outros para engenheiros e técnicos qualificados; e outros, ainda, para os operários não qualificados, assim como alguns clubes se restringiam aos moradores de determinados bairros da cidade planejada. Com isso, a estratificação e segregação a partir da diferenciação dos trabalhadores, que influenciavam a disposição das habitações e dos bairros no espaço urbano, também se refletiam no funcionamento do clube e na sua localização.

10 Dos seis clubes sociorrecreativos vinculados aos trabalhadores da CSN, um continua sendo administrado diretamente pela empresa, que é o clube "Recreio do Trabalhador Getúlio Vargas". 


\begin{tabular}{|c|c|c|}
\hline Nome & Tipo de equipamento & Atividades de lazer existente \\
\hline Clube Umuarama & Clube sociorrecreativo & $\begin{array}{l}\text { O clube foi construído exclusivamente para engenheiros e técnicos, principalmente americanos } \\
\text { que vieram para a construção da CSN. Havia atividades sociais e esportivas. Inaugurado em } \\
1956 \text {. }\end{array}$ \\
\hline Clube dos Funcionários da CSN & Clube sociorrecreativo & $\begin{array}{l}\text { Fundado em } 1942 \text { por iniciativa de um grupo de funcionários da CSN com o intuito de } \\
\text { desenvolver atividades de lazer e recreação. Realizava eventos em diversos locais até possuir } \\
\text { sede própria, já na década de } 1960 \text {. }\end{array}$ \\
\hline Aero Clube & Clube sociorrecreativo & $\begin{array}{l}\text { Criado em } 1943 \text { como clube aeronáutico com } 250 \text { sócios funcionários ou não da Companhia. } \\
\text { Tinha como objetivo formar pilotos civis e desenvolver a aeronáutica brasileira. Sua sede social } \\
\text { e toda infraestrutura foi construída em terreno da CSN por comodato. }\end{array}$ \\
\hline Clube Recreio do Trabalhador & Clube sociorrecreativo & $\begin{array}{l}\text { Complexo Esportivo construído pela CSN com a finalidade de promover lazer e esportes para os } \\
\text { operários e suas famílias. Inaugurado em } 1951 \text {. }\end{array}$ \\
\hline $\begin{array}{l}\text { Clube Náutico e Recreativo } \\
\text { Santa Cecília }\end{array}$ & Clube sociorrecreativo & $\begin{array}{l}\text { Fundado em } 1948 \text { para atender os funcionários técnicos e de baixa qualificação. No local havia } \\
\text { uma estrutura de madeira para promover entretenimento para os funcionários da CSN e mais } \\
\text { tarde passou a possuir sede própria. }\end{array}$ \\
\hline Clube Laranjal & Clube sociorrecreativo & $\begin{array}{l}\text { Foi fundado em } 1965 \text { por engenheiros, supervisores, gerentes e diretores da CSN residentes no } \\
\text { bairro. Ao longo dos anos construiu-se no terreno cedido pela Companhia, além da sede social, } \\
\text { toda uma infraestrutura de piscinas e campos de futebol. }\end{array}$ \\
\hline $\begin{array}{l}\text { Cinema Santa Cecília } \\
\text { (Poeirinha) }\end{array}$ & $\begin{array}{l}\text { Cinema (não existe } \\
\text { atualmente) }\end{array}$ & $\begin{array}{l}\text { Conhecido como "Poeirinha", foi o primeiro cinema de Volta Redonda, funcionando a partir de } \\
\text { 1946. Construído pela CSN para seus funcionários. }\end{array}$ \\
\hline Cinema 9 de Abril & Cinema & $\begin{array}{l}\text { Construído por iniciativa do Clube dos Funcionários da CSN e inaugurado em 1959. Possui } \\
\text { capacidade para } 1500 \text { pessoas e teve por finalidade levar cultura e entretenimento para os } \\
\text { trabalhadores da empresa. }\end{array}$ \\
\hline $\begin{array}{l}\text { Clube Círculo Operário de Volta } \\
\text { Redonda }\end{array}$ & $\begin{array}{l}\text { Entidade sociocultural } \\
\text { (não existe atualmente) }\end{array}$ & $\begin{array}{l}\text { Fundado em 1946. Inicialmente Círculo Operário de Volta Redonda mais tarde passou a chamar } \\
\text { Círculo dos Trabalhadores Cristãos. Começou como um barracão de madeira que proporcionava } \\
\text { aos trabalhadores lazeres populares com shows, peças de teatro e domingueiras dançantes. }\end{array}$ \\
\hline
\end{tabular}

Tabela 1 - Equipamentos que direta ou indiretamente eram utilizados para as atividades de lazer pelos trabalhadores da CSN.(conclusão)

\begin{tabular}{|c|c|l|}
\hline \multicolumn{2}{|c|}{ Tabela 1-Equipamentos que direta ou indiretamente eram utilizados para as atividades de lazer pelos trabalhadores da CSN.(conclusão) } \\
\hline Rádio Siderúrgica Nacional & $\begin{array}{l}\text { Retransmissora de rádio } \\
\text { (não existe atualmente) }\end{array}$ & $\begin{array}{l}\text { Inaugurada em 1955 e retirada do ar em 1980. Foi criada para proporcionar lazer e contribuir } \\
\text { para a educação dos jovens a época, a maioria filhos dos funcionários da CSN além da função de } \\
\text { reforçar valores e ideologias da empresa. Tinham uma programação de valorização da música } \\
\text { popular brasileira e da música clássica com finalidade educacional e cultural. }\end{array}$ \\
\hline Clube Foto-Filatético & Entidade sociocultural & Fundado em 1954 tem por finalidade difundir artes, fotografias, filatelia, numismática e cultura. \\
\hline
\end{tabular}




\begin{tabular}{|c|c|l|}
\hline & sem fins lucrativos & $\begin{array}{l}\text { Nas décadas de 1960 e 1970 era comum a participação da entidade em eventos nacionais e } \\
\text { internacionais. Hoje promove exposições e cursos. }\end{array}$ \\
\hline Teatro Santa Cecília & Teatro & $\begin{array}{l}\text { Foi Fundado pela CSN, sendo inaugurado em 1955. Promovia espetáculos teatrais e atividades } \\
\text { de caráter educativo e social. Funcionou como escola primária. Atualmente pertence à Igreja } \\
\text { Católica, atendendo a comunidade carente com diversas atividades. }\end{array}$ \\
\hline $\begin{array}{c}\text { Grêmio Artístico e Cultural } \\
\text { Edmundo Macedo Soares e Silva }\end{array}$ & Entidade sociocultural & $\begin{array}{l}\text { Fundada em 1945. Passou a ter sede própria na década de 1960 promovendo atividades culturais } \\
\text { e artísticas como espetáculos teatrais, músicas, danças, recitais, concertos, exposições de artes, } \\
\text { difusão cultural e artística entre outras. }\end{array}$ \\
\hline Hotel Bela Vista & $\begin{array}{l}\text { Foi construído durante a década de 1940 sendo inaugurado por etapas. Nos seus salões e áreas de } \\
\text { lazer eram realizados shows e bailes para os funcionários mais graduados da CSN. }\end{array}$ \\
\hline Grupo Escolar Trajano de Medeiros & Escola & $\begin{array}{l}\text { Escola projetada pela CSN para atender filhos de funcionários de baixa qualificação, sendo } \\
\text { inaugurada em 1946. Possui auditório com poltronas adequadas para o público assistir a filmes, } \\
\text { peças, shows, reuniões, possuindo uma boa acústica e camarins para abrigar artistas. }\end{array}$ \\
\hline Estádio Sylvio Raulino de Oliveira & Estádio de Futebol & $\begin{array}{l}\text { Foi construído no final dos anos 1940 pelo General Sylvio Raulino de Oliveira, então presidente } \\
\text { da CSN, que o financiou. Em 1959, o General Raulino passou a administração do estádio para } \\
\text { Guarani Futebol Clube, através de comodato. }\end{array}$ \\
\hline
\end{tabular}

Fonte: ARQUIVO CENTRAL DA CSN, 2012. 
Figura 03 - Mapa com a localização dos equipamentos de lazer vinculados a CSN em Volta Redonda-RJ nas décadas de 1950 e 1960.

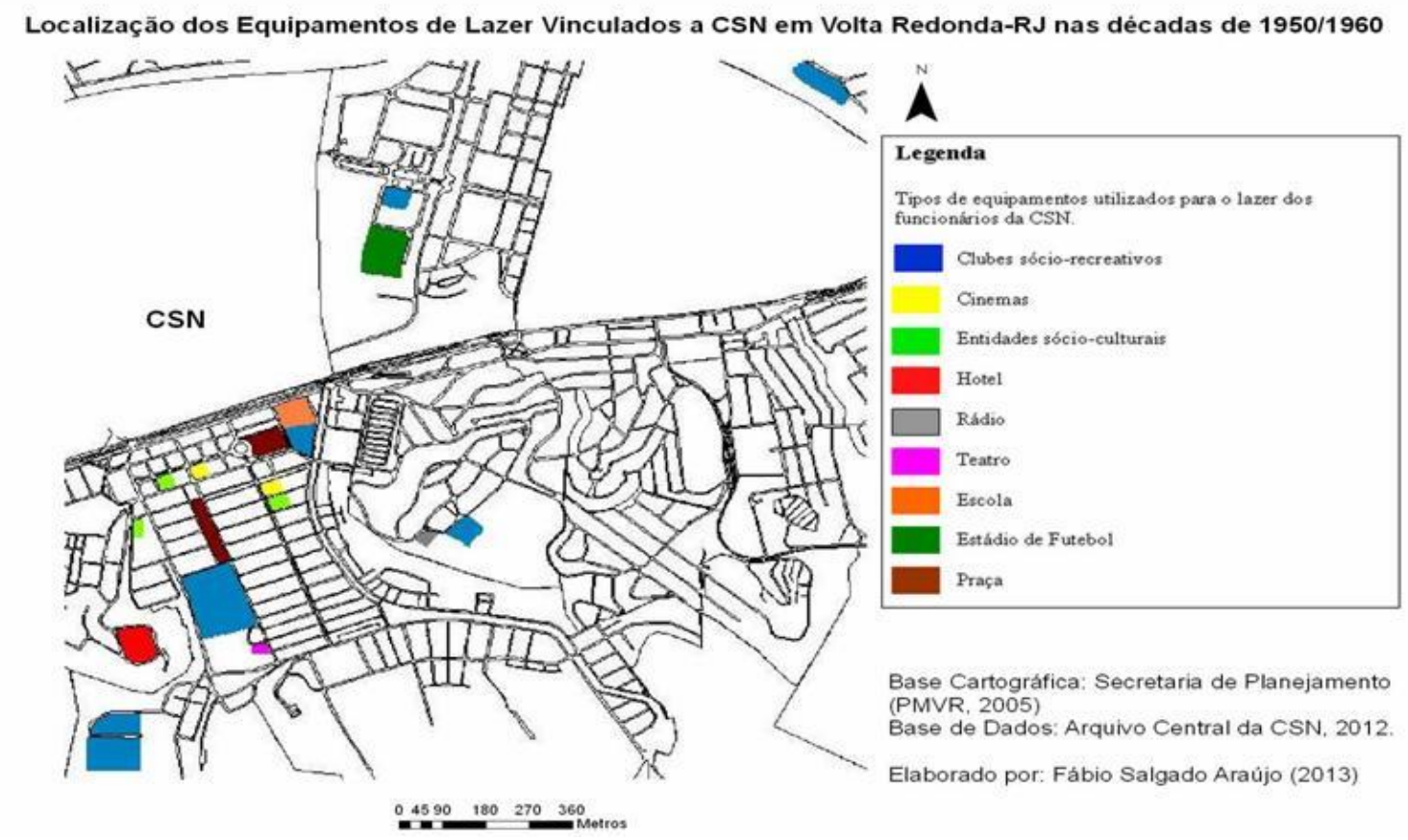

Fonte: O autor, 2013.

Diante disso, enquanto exemplos empíricos foram estudados dois dos clubes sociorrecreativos mais significativos ligados aos trabalhadores da CSN e que ainda mantêm suas atividades: o Clube dos Funcionários da CSN e o Clube Recreio do Trabalhador Getúlio Vargas.

\section{O Clube Sociorrecreativo Funcionários da CSN}

O primeiro dos clubes sociorrecreativos criados por empregados da empresa foi o Funcionários da CSN. A iniciativa surgiu em 18 de fevereiro de 1942, quando um grupo de funcionários da empresa de origem paulista decidiu criar um clube em Volta Redonda, à época ainda distrito de Barra Mansa. Esses funcionários tinham sido impedidos de entrar no baile de carnaval daquele ano no Clube Municipal de Barra Mansa, o principal da região na época. Posteriormente, a data de aniversário do Clube 
ficou definida como 9 de abril, a mesma data de inauguração e aniversário da CSN, o que evidencia a maneira como os funcionários reforçavam a sua relação com a empresa. Inicialmente, o clube funcionou em um barracão na área da usina e, ao longo dos anos, construiu uma infraestrutura destinada aos seus associados, exclusivamente funcionários da CSN.

No início, no barracão dentro da obra eram realizadas as festas, reuniões sociais e bailes. O objetivo era promover atividades sociais, culturais e esportivas em alto nível para seus associados. Desde o primeiro instante, o clube era caracterizado como uma associação destinada aos funcionários mais qualificados da empresa, que compunham os quadros de diretores e associados. As atividades promovidas eram assim voltadas para um grupo seleto dos funcionários, que exerciam os cargos mais elevados, como chefes de setor, engenheiros e técnicos qualificados.

Com a inauguração do Hotel Bela Vista, no final da década de 1940, o clube passou a organizar vários eventos, muitos em conjunto com o clube Umuarama, também destinado aos trabalhadores mais qualificados. Destacavam-se os bailes de carnaval, as festividades em homenagem à fundação da CSN, festas juninas, Natal e réveillon. As festas possuíam um alto grau de sofisticação Figura 04 e no anúncio da festa em comemoração ao $13^{\circ}$ aniversário da CSN, em 1954:

(o clube Funcionários) [...] oferecerá ao seu quadro social um grandioso baile no dia 10 de abril que será abrilhantado pela Orquestra Bandeirante e seu melódicos, da Capital da República. Na oportunidade serão distribuídos convites entre os componentes das Delegações dos Setores que aqui estarão para os festejos comemorativos a mais um aniversário da CSN. Traje - passeio completo $^{11}$ (Programação dos Clubes, 1954. Jornal O Lingote, ano II, Rio de Janeiro, $n^{\circ} 31$, junho de 1954).

\footnotetext{
11 Traje passeio completo: o masculino inclui o uso completo do terno com gravata, meia social e sapatos; para as mulheres, vestido longo.
} 
Figura 04 - Baile em homenagem à Rainha do Aço promovido pelo Clube dos Funcionários da CSN no Hotel Bela Vista, em 1951.

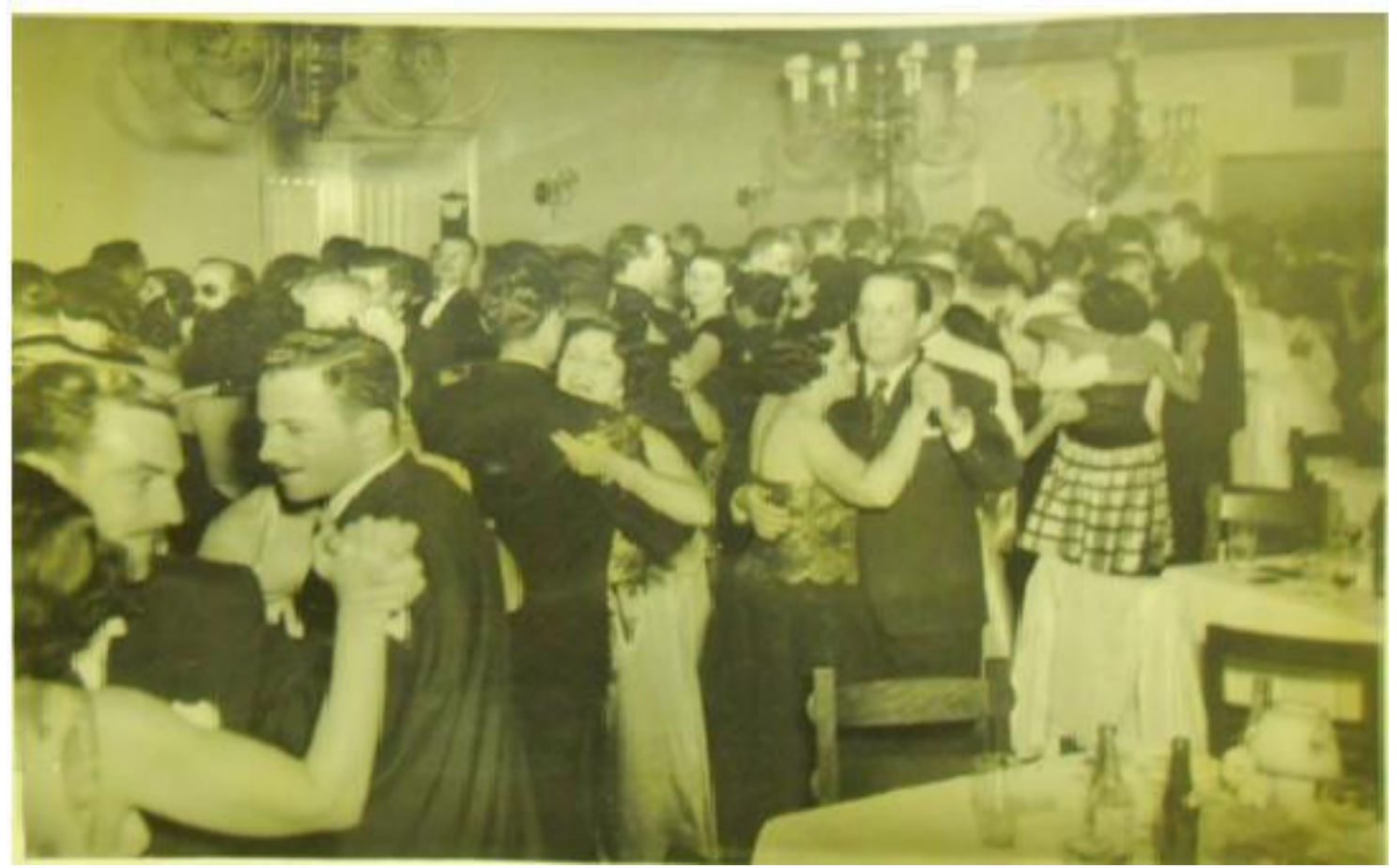

Fonte: ARQUIVO CENTRAL DA CSN, 2013.

Em 1959, ainda sem ter sede própria, o clube construiu o Cinema 9 de abril, na Vila Santa Cecília. De acordo com Diniz e Carneiro (2009), para a construção do cinema foram apresentados diversos anteprojetos até a elaboração do definitivo, cujos responsáveis foram o arquiteto Glauco do Couto Oliveira e o projetista Ricardo Tommasi. Além da exibição de filmes, o local recebeu muitos espetáculos de teatro e shows. O cinema contava (e ainda conta) com capacidade para 1500 pessoas, amplos espaços e escadarias imponentes para a época. Os revestimentos dos pilares, das paredes, pisos e tetos utilizavam cores e texturas que atestavam a apropriação do vocabulário modernista em voga no contexto da construção de Brasília. Ao longo dos anos, o cinema passou por obras de reforma, mas ainda preserva as características originais na fachada (FIGURA 05). 
Figura 05 - Mosaico de fotos mostrando a fachada do Cinema 9 de Abril.
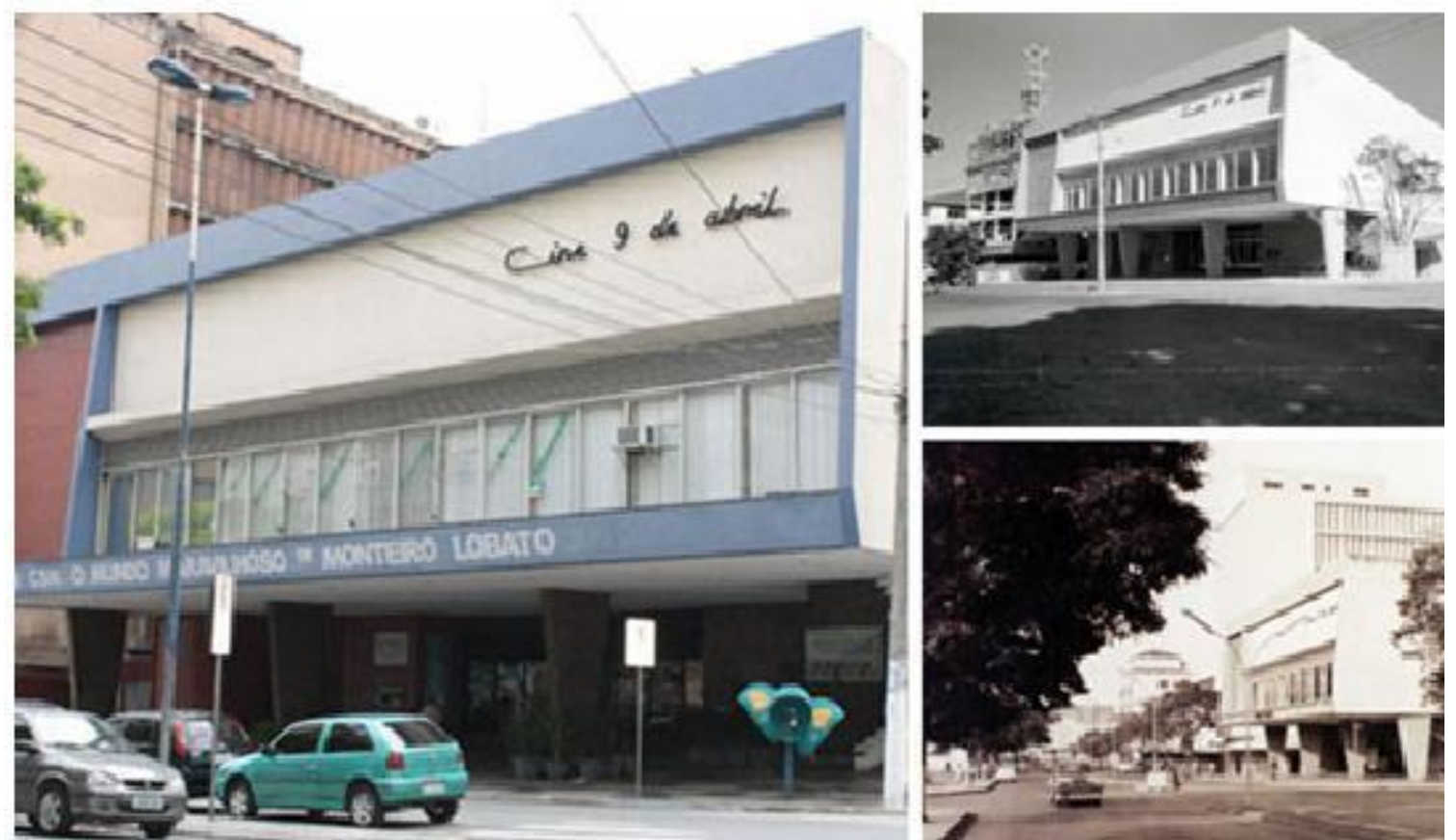

Fonte: CLUBE DOS FUNCIONÁRIOS DA CSN, 2013.

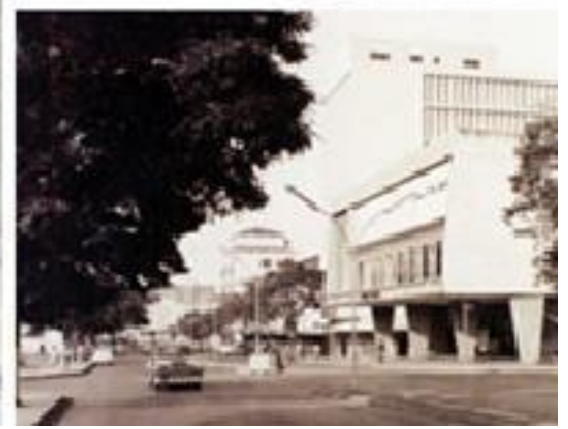

Durante as décadas de 1960 e 1970, sob a administração do clube Funcionários, o cinema era frequentado pelas classes média e alta do município, com destaque para os funcionários mais qualificados da empresa. A programação dos cinemas da cidade era publicada quinzenalmente n'O Lingote, com destaque para as sessões do Cine 9 de Abril. As sessões aos fins de semana eram concorridas e pode-se observar também os trajes usados pelos presentes (FIGURA 06). Em algumas sessões, o uso de traje da gala era obrigatório, mas, mesmo nas sessões abertas, parte dos frequentadores o usava, pois o local era frequentado pela elite da cidade. Esta era, decerto, uma das diferenciações para os outros dois cinemas existentes naquele período.

Atualmente o Cinema 9 de abril continua com a exibição de filmes e espetáculos musicais e teatrais sob administração do clube. Considerados um dos maiores cinemas de rua ainda em funcionamento no Brasil, ele é apresentado como um dos orgulhos do clube, como pode ser observado na fala do presidente, Renato Santini: 
[...] durante décadas o cinema foi o ponto de encontro da cidade. Aos fins de semana, os homens vestiam ternos e as mulheres vestidos longos para assistir aos filmes. Até hoje o cinema exibe os principais lançamentos da indústria cinematográfica, e apresenta shows de teatro e música praticamente todas as semanas ${ }^{12}$.

Em 1962, o clube inaugurou sua sede social ao lado do 9 de abril, em terreno cedido pela CSN. Com a contribuição dos associados do clube e o objetivo de atendêlos, o prédio de oito andares possuía um salão de festas com capacidade para 2 mil pessoas, salão de jogos e salas comerciais (estrutura ainda mantida nos dias atuais). Possuindo sede social própria, o clube passou a realizar um maior número de eventos para seus associados e convidados, ocorrendo bailes e shows semanalmente. Tais eventos continuavam destinados a um público restrito, que se resumia aos associados e alguns convidados. Os bailes eram sofisticados, o salão especialmente ornamentado, e as pessoas portavam trajes finos (FIGURA 07).

Figura 06 - Sessão de cinema no 9 de Abril ao final da década de 1960.

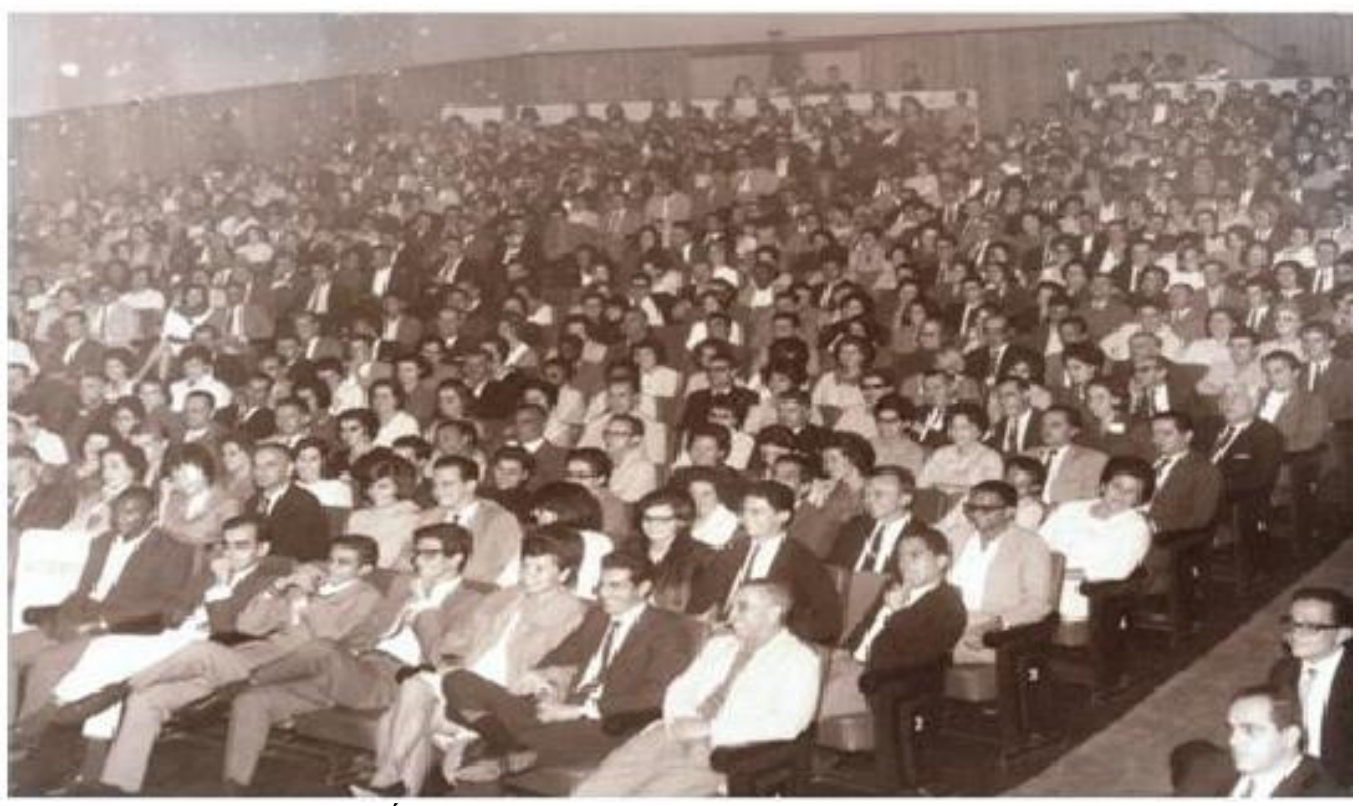

Fonte: CLUBE FUNCIONÁRIOS DA CSN, 2013.

12 Entrevista concedida pelo presidente do Clube dos Funcionários CSN, Renato Santini durante as comemorações dos 70 anos do clube. "Especial - 70 Anos de um Gigante do Interior" (CLUBE DOS FUNCIONÁRIOS DA CSN, 2012). 
Figura 07 - Baile na sede social dos Clubes dos Funcionários em 1965.

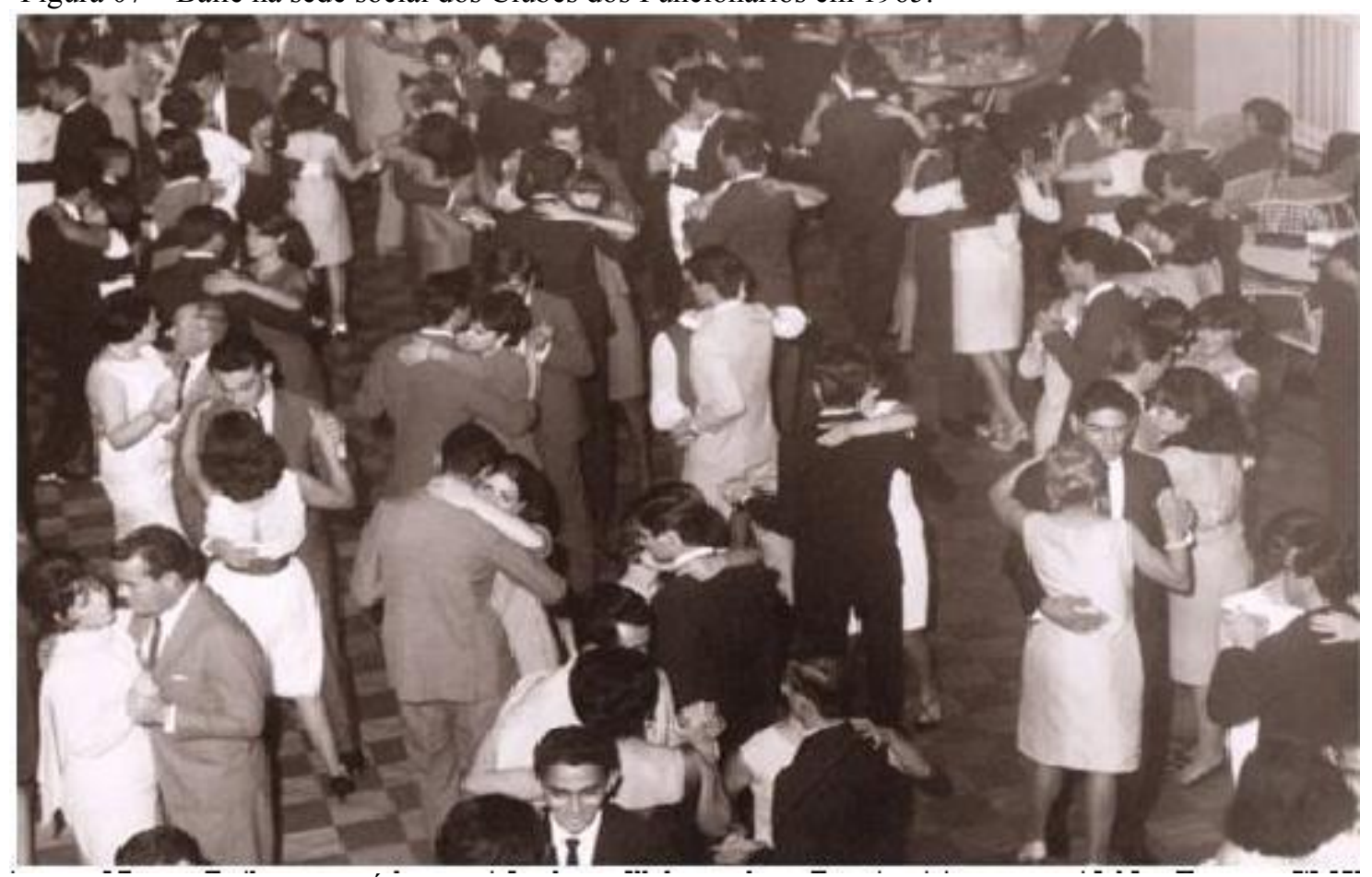

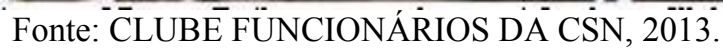

Em 1965, em uma área verde ao fundo do bairro Vila Santa Cecília, foi cedido pela CSN, em comodato, o local para a construção da Praça de Esportes Tabajara. A empresa contribuiu ainda cedendo máquinas, equipamentos e funcionários para que na área, de 158 mil metros quadrados, fosse construído o complexo de esporte e lazer, levando o Clube dos Funcionários a ser considerado o maior clube sociorrecreativo existente no interior do estado do Rio de Janeiro. Ao longo das décadas seguintes, uma série de obras foi realizada, como a construção do parque aquático, a partir de 1972, e de um ginásio poliesportivo, construído em 1998.

Atualmente, o clube possui cinco quadras de tênis, três quadras poliesportivas, três campos de futebol society, academia de ginástica, quadras de padel, futevôlei e peteca, parque infantil, churrasqueiras, restaurante, lanchonetes, saunas e salões de festa. Possui ainda o parque aquático, com quatro piscinas, sendo uma olímpica, e o 
ginásio poliesportivo, com capacidade para 5200 pessoas, que, além de receber torneios esportivos, é um local onde acontecem festas e bailes do clube.

De acordo com dados fornecidos pela secretaria, o clube atualmente possui 10670 associados. Nos dias atuais, para se associar não precisa mais ser funcionário da CSN, mas o clube ainda mantém uma seletividade. Para tal, o pretendente deverá preencher uma proposta abonada por um associado e deverá se comprometer a cumprir o estatuto do clube. A proposta passa por uma triagem da direção, avalia-se se o candidato possui bom conceito na sociedade e, em seguida, leva-se para apreciação e julgamento em reunião da diretoria.

O discurso da atual diretoria, com o slogan faça do clube a sua casa, é de proporcionar uma vivência familiar, em que o associado pode participar dos eventos promovidos com a tranquilidade, o prazer e a sensação de estar em sua própria casa. Para isso, o clube afirma que investe em eventos de alto nível. Esse discurso é uma das características dos clubes sociorrecreativos; no caso do Funcionários da CSN, nota-se até uma semelhança com o discurso da família siderúrgica.

Assim, apesar das transformações na CSN e no município, o clube mantém uma postura que se assemelha àquela dos tempos de sua fundação. O caráter de exclusividade para os sócios, a restrição às visitas, a rigorosidade na seleção dos associados e o padrão destes - majoritariamente classes média e média alta contribuem para que se diferencie dos demais espaços de lazer da cidade. Um exemplo dessa postura pode ser visto nos critérios de visitação, que restringe consideravelmente a visita de não sócios: cada associado pode levar até três convidados durante o ano, e cada um desses convidados pode retornar às dependências por no máximo mais duas vezes durante o ano; todas as vezes, mediante pagamento de taxas. $\mathrm{O}$ fato de o clube se 
localizar no topo de uma colina, cercado por uma área florestada, num bairro de classe média alta, com casas de alto padrão no entorno contribui para essa exclusividade aos seus associados.

De acordo com a secretaria, o clube é uma entidade sem fins lucrativos com orçamento anual de $\mathrm{R} \$ 5,5$ milhões, uma despesa mensal de cerca de $\mathrm{R} \$ 440$ mil e com quadro de aproximadamente cem empregados. A mensalidade cobre cerca de $50 \%$ das despesas, e a outra parte é coberta com aluguel das salas e lojas da sede social e dos espaços alugados para festas e eventos. Lá também se promovem escolinhas em diversas modalidades esportivas e dezenas de campeonatos e eventos esportivos regionais e nacionais durante o ano todo. São planejados novos investimentos para os próximos anos, principalmente na melhoria da infraestrutura visando ao atendimento do associado.

\section{O Clube Sociorrecreativo Recreio do Trabalhador}

Conforme já mencionado, o Estado Novo tinha a preocupação de difundir as ideias ligadas à imagem populista de Vargas, e nesse sentido empregaram-se meios de comunicação de massa, eventos esportivos e manifestações culturais (música, cinema, teatro etc.). Assim, durante a construção da siderúrgica e nos primeiros anos de funcionamento, foi instituído em Volta Redonda o Serviço de Recreação Operária ${ }^{13}$ (SRO), que se destinava a organizar o lazer dos trabalhadores e suas famílias. Com o intuito de construir um espaço para a prática dessas atividades, reservou-se na planta geral da cidade operária um local para a construção de um complexo esportivo e

\footnotetext{
13 Subordinado à Comissão Técnica de Orientação Sindical do governo Getúlio Vargas (CTOS), o Serviço de Recreação Operária destinava-se a organizar o lazer dos trabalhadores e de suas famílias e tinha o objetivo de "coordenar os meios de recreação da classe operária, prestando aos sindicatos assistência e colaboração" (BRETAS, 2010).
} 
cultural, em um terreno plano na Vila Santa Cecília. Dando sequência ao planejamento, no ano de 1951 foi inaugurado o Clube Recreio do Trabalhador (mais tarde chamado Clube Recreio do Trabalhador Getúlio Vargas), numa área de 47 mil metros quadrados (FIGURA 08).

O clube tinha como objetivo atender, preservar, recuperar e aumentar a capacidade de produzir do trabalhador, sendo considerado pela empresa como um elemento importante do programa de assistência social que ela dispensava aos seus empregados. O complexo esportivo era composto de um ginásio coberto, com capacidade para 6 mil espectadores e uma piscina de dimensões olímpicas. Possuía ainda um estádio de futebol, pista de atletismo e concha acústica.

Figura 08 - Fotografia do Clube Recreio do Trabalhador, 1961.

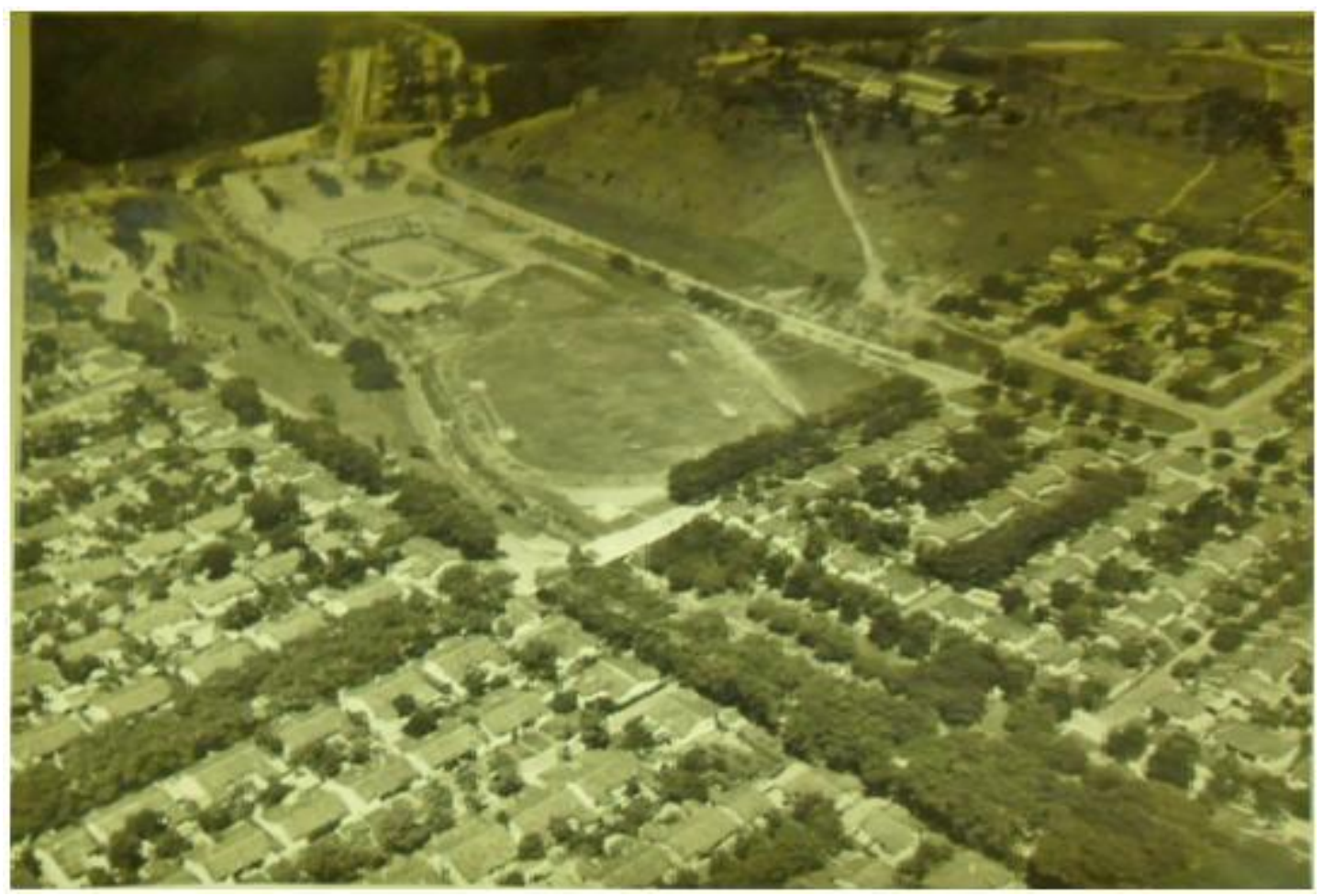

Fonte: ARQUIVO CENTRAL DA CSN, 2013. 
Durante as obras do complexo, o discurso da CSN procurava exaltar sua significativa importância e grandiosidade, que esta transformava a cidade, como se pode ler no trecho extraído do jornal da empresa:

À medida que progridem as obras de construção do Recreio do Trabalhador, adquire aspectos novos a cidade do aço. $\mathrm{O}$ primeiro edifício a modificar o panorama foi o ginásio desportivo, cujas linhas arquitetônicas causaram desde o início a melhor impressão. Agora, ultima-se a construção da piscina olímpica e uma feição diferente toma o local (Aspecto Novo na Cidade do Aço, 1954. Jornal $O$ Lingote, ano II, Rio de Janeiro, $\mathrm{n}^{\mathrm{o}} 31$, junho de 1954, p. 12).

O ginásio, inaugurado em 1954, foi considerado um marco arquitetônico da cidade, pois, de acordo com Diniz e Carneiro (2009), a cobertura curva e as esquadrias laterais possibilitavam a ventilação e favoreciam o conforto ambiental. Os pilares em arco podiam ser observados externa e internamente (FIGURA 09). Quando foi erguido, era o único espaço coberto de grande porte na cidade, e a cobertura, aliada ao palco, possibilitava também a utilização do espaço para apresentações culturais diversas, shows e solenidades políticas.

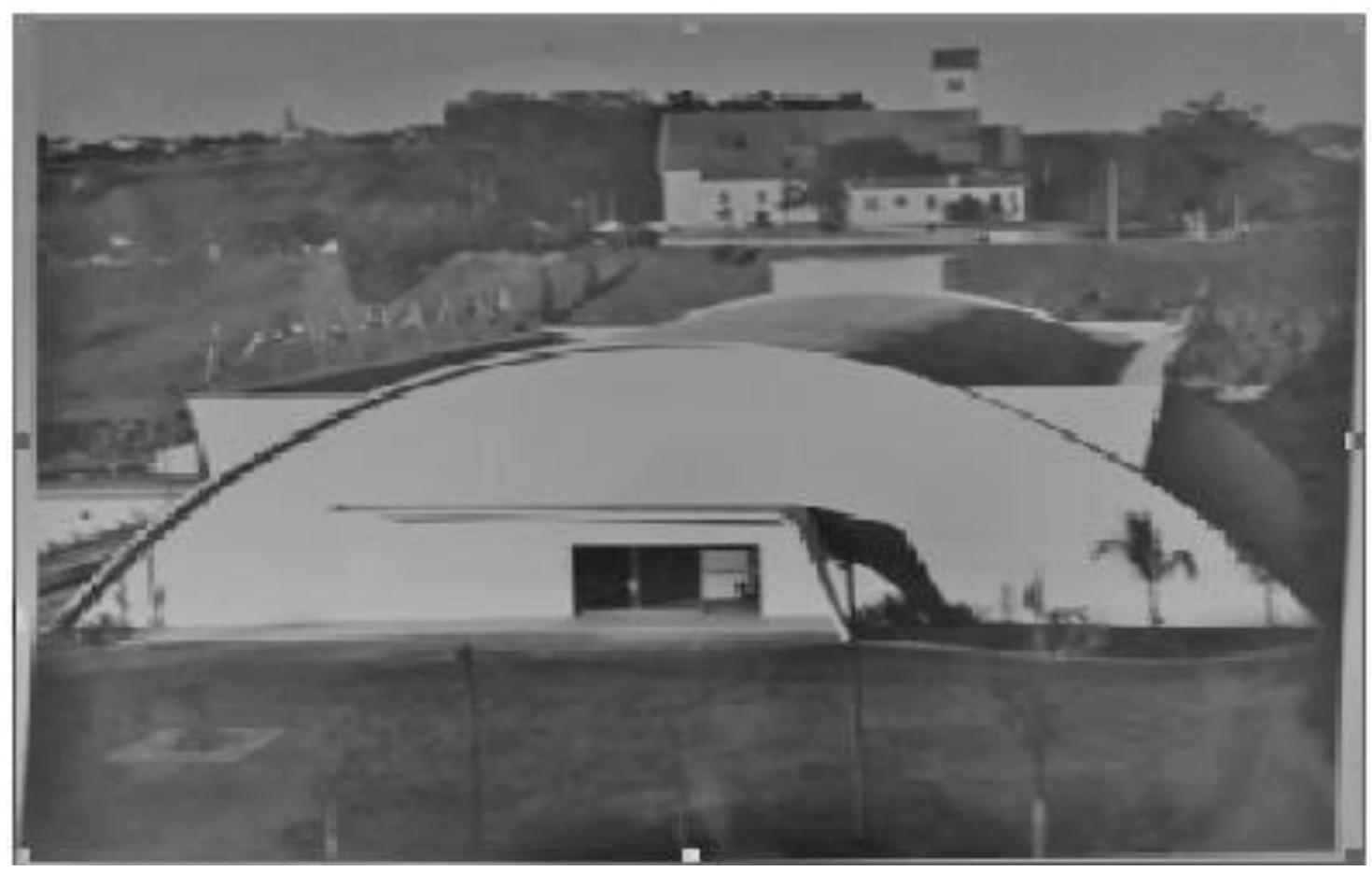


Figura 09 - Fotografia externa do ginásio do Clube Recreio do Trabalhador, 1954. Fonte: ARQUIVO CENTRAL DA CSN, 2013.

Considerada a primeira de dimensões olímpicas no interior do país, a piscina do clube foi inaugurada em 1955. A empresa utilizou a inauguração para apresentar a obra como um marco de desenvolvimento da cidade, com aspectos arquitetônicos modernos e da política de assistência social destinada aos trabalhadores. Além disso, procurou envolver a população na participação nas festividades que envolveram a inauguração da obra. Observa-se esse discurso na veiculação da nota de inauguração da obra:

Reunindo na cidade do aço mais de 20 mil pessoas, muitas das quais procedentes das cidades vizinhas de Barra Mansa, Barra do Piraí e Resende, as festividades de inauguração da piscina olímpica do Recreio do Trabalhador de Volta Redonda constituíram um acontecimento de grande relevo, marcado pela mais vibrante e entusiástica participação do povo. Apresentando belo aspecto arquitetônico, a nova unidade esportiva está aparelhada com todos os recursos necessários às competições de natação, inclusive trampolim de vários tipos para saltos ornamentais apresentando, ainda todos os requisitos indispensáveis à garantia de rigorosa higiene. (Mais de 20.000 Aplaudiram, 1955. Jornal O Lingote - Ano II - Rio de janeiro, $\mathrm{n}^{\mathrm{o}} 44$ - Janeiro de 1955, p. 12).

O clube era destinado somente aos trabalhadores da CSN e suas famílias, mas era aberto a visitas. Para a utilização do Recreio do Trabalhador era descontado um valor no contracheque do trabalhador, dando direito ao cônjuge e aos filhos de usufruir a infraestrutura e as atividades oferecidas pelo clube, que possuía cerca de 30 mil associados. Assim, com a institucionalização desse espaço de lazer, os trabalhadores dispunham de uma referência espacial que condicionava formas de comportamento através de atividades lúdicas, tipos de trajes, assuntos discutidos etc. Destacavam-se as atividades esportivas, os shows e bailes realizados nas dependências do clube.

De acordo com Fernandes (2001), nesse espaço era oferecido ao trabalhador todo tipo de divertimento, desde torneios esportivos até festas, shows e maratonas estudantis. Ainda conforme diz a autora, os trabalhadores guardaram lembranças 
positivas do clube e do que tiveram oportunidade de vivenciar nele, pois tiveram naquele contexto acesso a bens culturais produzidos nos grandes centros e aos quais poucos trabalhadores, em poucas partes do país, tinham acesso. Com isso, sentiam-se inseridos no mundo cultural dos principais centros urbanos, firmando uma identidade local e original de uma cidade que, além de produzir aço, era moderna e produzia vencedores em outras áreas da criação humana.

Nas décadas de 1950, 1960 e 1970 destacavam-se as atividades esportivas, principalmente os esportes coletivos como futebol, basquete e vôlei. Essas modalidades tinham equipes formadas por trabalhadores da CSN que disputavam campeonatos regionais e nacionais (FIGURA 10). Através das competições, destacavam e divulgavam não somente o clube, mas também a empresa enquanto exemplo da "família siderúrgica". Também nesse período, no que diz respeito às festas e shows, destacavamse os bailes de carnaval e a apresentação de artistas da "Era do Rádio", que faziam lotar o ginásio do clube (FIGURA 11). Recuperar, reabilitar e ocupar eram as palavraschave dessa perspectiva funcionalista que permeou as atividades de lazer oferecidas pela CSN, sendo o clube Recreio do Trabalhador seu maior exemplo.

Em 1990, a CSN passa a administração do Recreio para a FUGEMSS (mais tarde Fundação CSN), que promoveu uma série de mudanças na administração e organização do clube. A partir de então, a associação passou a ser aberta para pessoas que não possuem vínculo com a empresa. Houve também um aumento no valor das mensalidades, levando muitos a deixarem de se associar ao clube. De acordo com informações passadas pelo clube, em 2006 eram 10500 sócios e, atualmente (2013), são 5 mil sócios e 1700 alunos inscritos nas escolinhas esportivas. 
Figura 10 - Mosaico de fotos de equipes no clube.

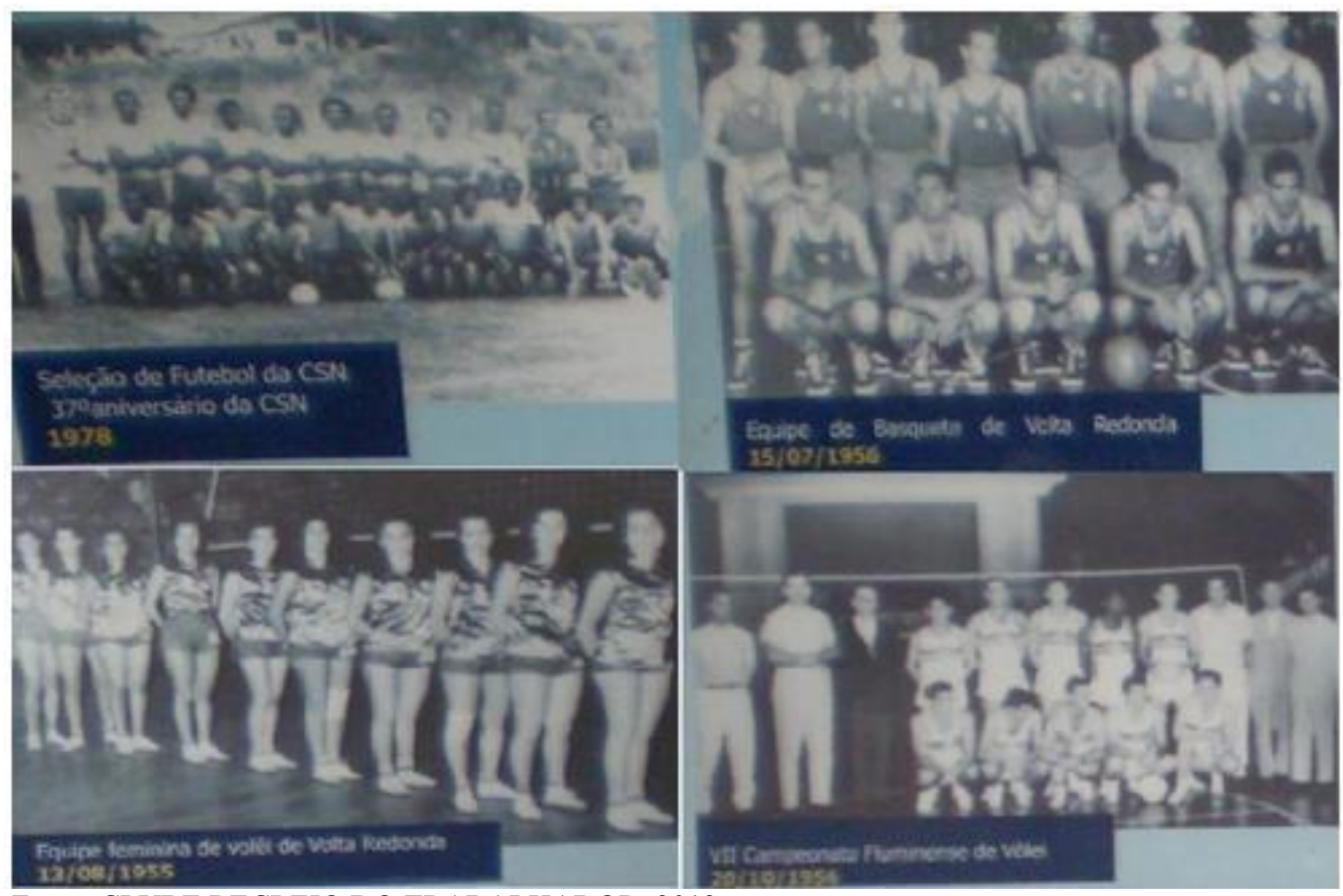

Fonte: CLUBE RECREIO DO TRABALHADOR, 2012.

Figura 11 - Fotografia das comemorações do "Dia do Radialista" no ginásio do Recreio do Trabalhador, 1955.

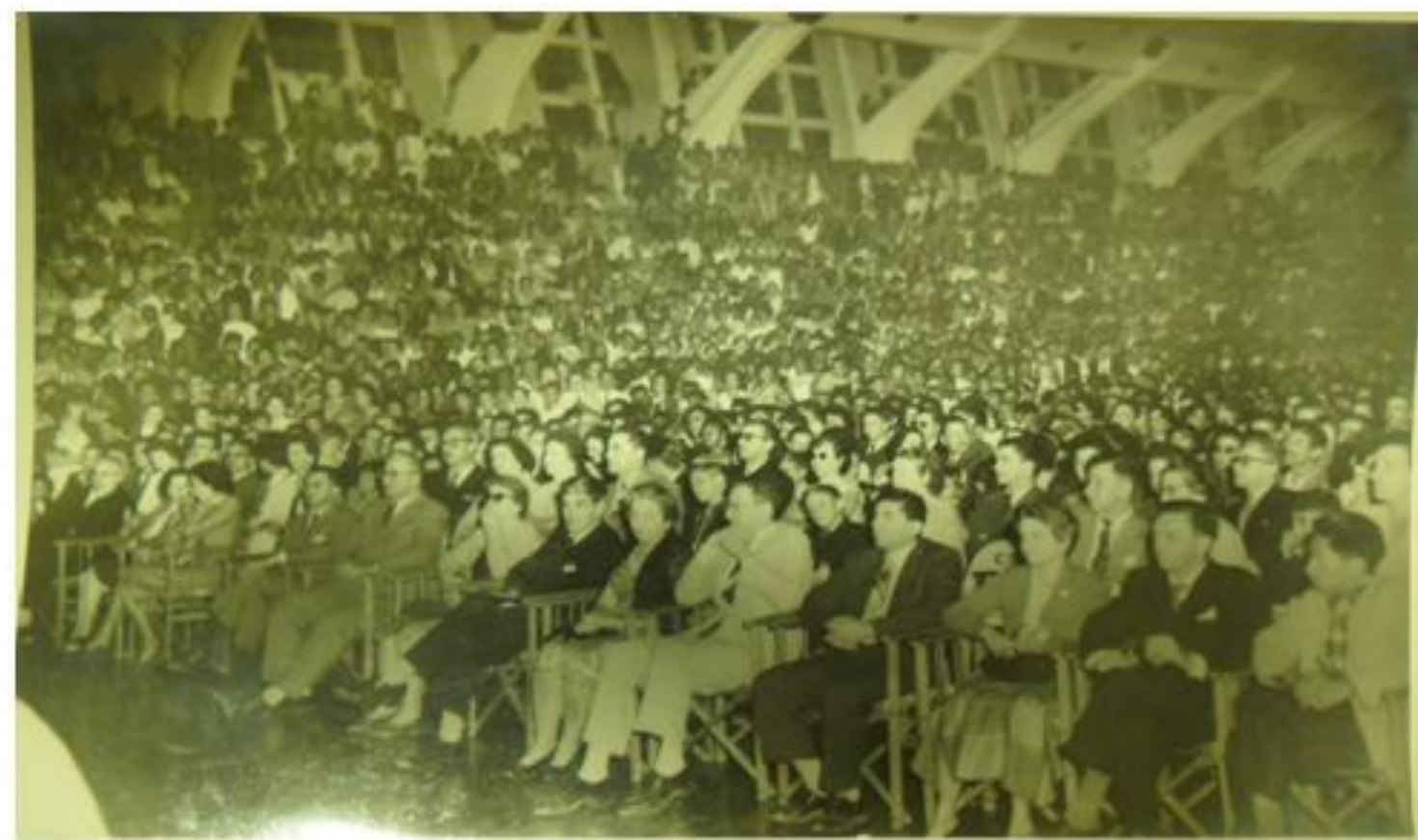

Fonte: ARQUIVO CENTRAL DA CSN, 2013. 
Na última década, foram feitos alguns investimentos, como a reforma, em 2002, que transformou o campo de futebol em quadras de tênis, dois campos de futebol society (um de grama sintética e outro de grama natural), quiosque com churrasqueira, duchas e uma academia. Apesar disso, muitos associados e ex-associados reclamam da falta de investimentos em novas atividades esportivas e cultural-artísticas. E não está programado, de acordo com informações do clube, investimentos em infraestrutura para os próximos anos.

Atualmente, o clube é utilizado para projetos de inclusão social, principalmente através do esporte, com a instituição do Programa Esportivo e Social (PES), criado com o objetivo de contribuir para a inclusão de crianças e adolescentes do sul fluminense em situação de vulnerabilidade social. Assim, a Fundação CSN, enquanto braço social da empresa, agora privatizada, é responsável pelo cumprimento das ações sociais, utilizando para isso, sobretudo, o clube.

\section{Considerações Finais}

Na época da CSN estatal, o lazer sustentado pela empresa destinava-se somente aos seus funcionários e de maneira estratificada. Dessa forma, havia um lazer diferenciado de acordo com as faixas salariais e os cargos dos trabalhadores. Aqueles que não trabalhavam na CSN não podiam utilizar os equipamentos de lazer a ela vinculados. Diante disso, os comerciantes e os profissionais liberais estabeleciam seu próprio lazer; assim como a população de baixa renda do município, que praticava o lazer de forma precária ou simplesmente não tinham acesso.

As características do lazer vinculado à empresa objetivavam construir um novo trabalhador, condicionando seu corpo, mente e espírito às exigências da nova 
civilização mecânica e com os valores morais na criação de uma sociedade urbanoindustrial de caráter fordista em formação no país. $O$ entendimento dessas características de lazer ocorre sobre a perspectiva funcionalista em consonância com os valores industriais fordistas. Assim, Dumazedier $(1973,1979)$ e Parker (1976) são fundamentais na compreensão do lazer durante esse período, pois suas obras identificam que o lazer ganha cada vez mais centralidade constituindo-se em uma preocupação, pois é um conjunto de atividades que divergem das atividades produtivas, ligadas ao trabalho e das obrigações sociais. A empresa, compreendendo esse processo, procura desenvolver atividades para preencher o tempo de não-trabalho de seus funcionários.

O objetivo principal do lazer para a empresa era recuperar os trabalhadores e compensar os desgastes originados nas atividades obrigatórias, além de controlar o tempo de não trabalho de seus funcionários. Assim, buscava uma "paz social" através da instrumentalização do lazer. O lazer industrial é fonte de valores éticos onde a siderúrgica procura estabelecer influências coletivas sociais mais fortes que as individuais. Com isso, há o controle por parte da empresa dos espaços de lazer dos trabalhadores onde estes só poderiam praticar atividades de lazer em consonância com os valores da empresa.

Assim, verificamos que dentre os equipamentos de lazer vinculados à empresa, os clubes sociorrecreativos são os mais significativos devido à quantidade de associados, às inúmeras atividades desenvolvidas e ao tamanho de suas infraestruturas. Cada clube possuía características próprias para atender determinado perfil de trabalhador e suas demandas. Com isso, dois exemplos foram significativos: o Clube Recreio do Trabalhador, administrado diretamente pela usina e voltado para o quadro geral de seus trabalhadores, principalmente aqueles de faixas salariais mais baixas e que 
exerciam profissões mais simples; e o Clube dos Funcionários da CSN, administrado diretamente pelos trabalhadores e voltado para um conjunto daqueles mais específicos, com faixas salariais mais altas e que ocupavam principalmente cargos de chefia.

\section{REFERÊNCIAS}

ASPECTO Novo na Cidade do Aço. O Lingote. Jornal Quinzenal da Companhia Siderúrgica Nacional. 1954. Rio de Janeiro, v.2, n. 31, p.10.

BÊDE, W. Volta Redonda na Era Vargas (1941-1964). Volta Redonda: SMC/PMVR, 2004.

BRETAS, A. O Serviço de Recreação Operária (1943-1945): uma experiência do governo Vargas no campo do não-trabalho. Caderno Arquivo Edgard Leuenroth esportes e trabalhadores, Campinas, v.16, n.28, p.149-174, 2010.

CALIFE, M. N. da S. A Relação entre Capital-Trabalho na Gênese da CSN. 2000. 128f. Dissertação (Mestrado) - Faculdade de História, Universidade Severino Sombra, Vassouras, 2000.

CLUBE dos Funcionários da CSN. Especial - 70 Anos de um Gigante do Interior, 2012. Disponível em: http://www.clubedosfuncionarios.com.br/noticia/260/especial-os70-anos-de-um-gigante-do-interior/ . Acesso em: 20 de Fev. 2013.

COSTA, A. Volta Redonda, Ontem e Hoje. 3. ed. Volta Redonda. Masiero's, 1992.

DINIZ L. N.; CARNEIRO, M. P. G. de F. Os edifícios públicos de Glauco Oliveira na cidade projetada por Attilio Corrêa Lima. In: SEMINÁRIO DOCUMENTATION AND CONSERVATION MODERN MOVEMENT, 8. 2009, Rio de Janeiro. Anais... Rio de Janeiro, 2009. s/p.

DUMAZEDIER, J. Lazer e Cultura Popular. 3. ed. São Paulo: Perspectiva, 1973.

DUMAZEDIER, J. Sociologia Empírica do Lazer. 2. ed São Paulo: Perspectiva, 1979. (Coleção Debates)

FERNANDES, M. Volta Redonda: imaginários, memórias e identidades. 2001. 198p. Dissertação (Mestrado) - Faculdade de Comunicação Social, Universidade Federal do Rio de Janeiro, Rio de Janeiro, 2001.

FONTES, A. M. M.; LAMARÃO, S. T. N. Volta Redonda: história de uma cidade ou de uma usina. Revista Rio de Janeiro, Niterói, n. 18-19, p. 241-253, Jan/Dez. 2006. 
FUNDAÇÃO CSN. Educação, Cultura, Comunidade e Esporte. Disponível em: http://www.csn.com.br/irj/portal/anonymous?guest user=usr fundacao pt Acesso em: 12 de fevereiro de 2013.

GRÊMIO Artístico e Cultural Edmundo de Macedo Soares e Silva (GACEMSS). Quem Somos. Disponível em: <http://www.gacemss.com.br/v1/page/quemsomos.asp> Acesso em: 27 de Jan. 2013.

JÁ Começou a Olimpíada Siderúrgica. O Lingote. Jornal Quinzenal da Companhia Siderúrgica Nacional. 1954. Rio de Janeiro, v.2, n. 40, p.11.

LIGA de Desportos de Volta Redonda (LDRV) Estatuto social, 2012. Disponível em: http://www.ldvr.com.br/institucional.php Acesso em: 10 de janeiro de 2012.

LOPES, A. da C.. A Aventura da Cidade Industrial de Tony Garnier em Volta Redonda. 1993. 235f. Dissertação (Mestrado) - Instituto de Geociências, Universidade Federal do Rio de Janeiro, Rio de Janeiro, 1993.

MAIS 20.000 Aplaudiram. O Lingote. Jornal Quinzenal da Companhia Siderúrgica Nacional. 1955. Rio de Janeiro, v. 2, n. 44, p.12.

MOREIRA, R. da L. CSN: um sonho feito de aço e ousadia. Rio de Janeiro: Fundação CSN e CPDOC/Fundação Getúlio Vargas, 2000.

MOREL, R. L. de M.. A Ferro e Fogo Construção e Crise da "Família Siderúrgica", O Caso de Volta Redonda (1941-1968). 1989. 542f. Tese (Doutorado) Faculdade de Sociologia, Universidade de São Paulo, São Paulo, 1989.

PARKER, Stanley. A Sociologia do Lazer. Rio de Janeiro: Zahar, 1976.

PIQUET, R. Cidade-empresa: presença na paisagem urbana brasileira. Rio de Janeiro: Jorge Zahar, 1998.

PROGRAMAÇÃO dos Clubes. O Lingote Jornal Quinzenal da Companhia Siderúrgica Nacional. 1954. Rio de Janeiro, v. 2, n. 31p.17.

SILVA, M. R. A Estrutura dos Clubes Sócio-Recreativos na América do Sul: Primeiros Indicativos. In: ENCONTRO ASOCIACÍON SOCIOCULTURALES DEL DEPORTE, 1. 2008, Curitiba. Anais... Curitiba, 2008. s/p.

\section{Endereço do Autor:}

Fábio Salgado Araújo

Rua J - n 290 - Jardim Ponte Alta

Volta Redonda - RJ - 27.267-280

Endereço Eletrônico: fsalgadovr@gmail.com 